\title{
Reactive airways dysfunction syndrome (RADS) following exposure to toxic gases of a swine confinement building
}

\author{
Y. Cormier*, B. Coll**, M. Laviolette*, L.P. Boulet*
}

\begin{abstract}
Reactive airways dysfunction syndrome (RADS) following exposure to toxic gases of a swine confinement building. Y. Cormier, B. Coll, M. Laviolette, L.P. Boulet. (CERS Journals Ltd 1996.

ABSTRACT: We describe the case of a 58 year old male, who developed a reactive airways dysfunction syndrome (RADS) after exposure to a high level of toxic gases in a swine confinement building.

This previously healthy, nonatopic man developed moderate, partially reversible, airway obstruction and increased responsiveness within a month after the toxic exposure. The circumstances of the incident and the concomitant death of two sows make it likely that hydrogen sulphide was the causative agent.

To our knowledge, this is the first case of reactive airways dysfunction syndrome reported from swine confinement buildings and, therefore, should raise awareness of this potential risk in that work environment.

Eur Respir J., 1996, 9, 1090-1091.
\end{abstract}

*Unité de recherche, Centre de pneumologie, Hôpital and Université Laval, Ste-Foy, and **l'Hotel Dieu de Sherbrooke, Sherbrooke Québec, Canada.

Correspondence: Yvon Cormier, Hôpital Laval, 2725 Chemin Ste-Foy, Ste-Foy, Québec, Canada, G1V-4G5

Keywords: Asthma, occupational lung disease

Received: July 18 1995, Accepted after revision December 181995
The term "reactive airways dysfunction syndrome" (RADS) was coined in 1985 by BROoKs et al. [1] to designate an asthma-like condition that may develop following exposure to toxic gases. This syndrome appears shortly after exposure to the causative agent and is characterized by an increased nonallergic airway responsiveness, with symptoms of asthma, in a subject with no history of asthma prior to the exposure. Although the exposure is often unique, the syndrome may be long-lasting. This syndrome can occur after exposure to a variety of toxic gases, including chlorine, ammonia, acids and hydrogen sulphide [2-5]. Recent studies have described pathological changes on bronchia! biopsies in this syndrome at its chronic stage [6]. These changes consist mostly of a marked airway wall collagen deposition.

Swine confinement buildings are often highly contaminated with toxic gases, including ammonia $\left(\mathrm{NH}_{3}\right)$, hydrogen sulphide $\left(\mathrm{H}_{2} \mathrm{~S}\right)$, methane $\left(\mathrm{CH}_{4}\right)$ and $\mathrm{CO}_{2}$ [7]. Other respirable pollutants in swine building include organic dusts and endotoxin, and various microbiological products $[8,9]$. Exposure to liquid manure has been associated with sudden deaths due to toxic gas inhalations [10]. Exposure to swine confinement buildings can lead to acute or chronic respiratory symptoms [11]; however, no reports have described RADS as a consequence to exposure in this environment.

Considering the nature of toxic gases present in swine buildings and the known causes of RADS, it is quite conceivable that this condition could result from exposure to the environment in swine confinement buildings, if conditions were appropriate. We report the case of a 58 year old man who developed RADS after working in a swine confinement building.

\section{Case report}

A 58 year old white male was brought to a local hospital complaining of dizziness, chest tightness, cough and dyspnoea following exposure to toxic gases in a poorly- ventilated swine confinement building. The incident occurred after he had started a pit pump to agitate swine manure in order to turn it into a slurry for easier evacuation. He had performed that task a number of times before without any problem. However, on the day in question, the ventilator above the manure pit was not functioning. As he was doing this mixing procedure, he noticed the presence of higher than usual quantities of repugnant fumes and suddenly saw that nearby sows were falling unconscious. He himself became dizzy and short of breath, and barely managed to reach the outside door. The two sows nearest to the dung pit actually died.

On arrival at the hospital, his clinical examination was unremarkable except for laboured breathing. Chest radiographs were normal. Arterial blood gases revealed an acute respiratory alkalosis and a normal oxygen tension; $\mathrm{pH}=7.58$; arterial carbon dioxide tension $\left(\mathrm{Pa}_{\mathrm{a}}, \mathrm{CO}_{2}\right) 2.4$ $\mathrm{kPa}(18 \mathrm{mmHg})$; arterial oxygen tension $\left(\mathrm{Pa}, \mathrm{O}_{2}\right) 12.3 \mathrm{kPa}$ (92 $\mathrm{mmHg})$. Although the patient was still complaining of dyspnoea, his clinical condition improved with no specific treatment. No histamine or methacho-line challenge was obtained at that time.

One month later, the patient was seen by a consulting pneumologist because he continued to complain of shortness of breath. Forced expiratory flows showed a mild obstructive defect with a forced vital capacity (FVC) of $4.21 \mathrm{~L}$ (105\% predicted), forced expiratory volume in one second (FEV1) of $2.76 \mathrm{~L}$ ( $88 \%$ pred), and an FEV1/FVC 
ratio of 0.66 . A methacholine bronchoprovocation test [12] was positive at a provocative concentration of methacholine causing a 20\% drop in FEV1 (PC20) of 1.7 $\mathrm{mg} \cdot \mathrm{mL}^{-1}$. The patient was started on regular budesonide, $800 \mu \mathrm{g}$ twice daily, and inhaled terbutaline, $0.5 \mathrm{mg}$ on demand. With this medication, his dyspnoea improved but did not disappear. His lung function has remained stable and repeat bronchoprovocations (three times over the last year, between 6 and 18 months after the acute exposure) showed a persistent increased airway responsiveness, with $\mathrm{PC} 20$ values of $2.8,0.3$ and $2.5 \mathrm{mg} \cdot \mathrm{mL}^{-1}$.

Prior to the toxic inhalation, the patient had never had respiratory symptoms. He had ceased smoking 20 yrs previously. He had no familial history of atopy or asthma. Skin-prick test to common aeroallergens (including swine protein and swine urine) were negative, his serum immunoglobulin $\mathrm{E}$ (IgE) level was $15 \mathrm{mg} \cdot \mathrm{L}^{-1}$ (normal $<290 \mu \mathrm{g} \cdot \mathrm{L}^{-1}$ ), and his blood eosinophil count was normal at $0.1 \times 10^{9} \cdot \mathrm{L}^{-1}\left(\right.$ normal $\left.<0.5 \times 10^{9} \cdot \mathrm{L}^{-1}\right)$.

\section{Discussion}

Although no measurements of toxic gases were obtained, the symptoms experienced by the patient and the death of two sows make it probable that their ambient levels were very high and that ammonia and hydrogen sulphide were probable components. Hydrogen sulphide can reach very high levels in swine buildings [10]. At lower concentrations (50-200 parts per million (ppm)) this gas produces marked irritation to the respiratory tract including acute bronchitis. At higher levels (200-500 ppm) $\mathrm{H}_{2} \mathrm{~S}$ can induce pulmonary oedema and haemorrhage that is often fatal [13]. $\mathrm{H}_{2} \mathrm{~S}$ also causes acute neurological symptoms from giddiness and headache to coma and death, effects being dose-related [14]. The death of the sows and the neurological symptoms of our patient could be explained by high levels of $\mathrm{H}_{2} \mathrm{~S}$. We cannot prove that $\mathrm{H}_{2} \mathrm{~S}$ caused the RADS in our patient; it is quite possible that a combination of toxic gases was involved. RADS is characterized by acute and chronic airway inflammation [6], both could have been triggered by the exposure described.

This case is highly suggestive of RADS for a number of reasons. Firstly, the subject was exposed to an environment known to contain gases, of which at least two $\left(\mathrm{NH}_{3}\right.$ and $\left.\mathrm{H}_{2} \mathrm{~S}\right)$ are known to cause RADS [15]. Secondly, the patient had no personal or familial history of asthma or atopy. Thirdly, he had no respiratory symptoms prior to the exposure. Fourthly, he has no current evidence of allergy. Finally, the sequence of events fit the pattern described in RADS. This case, therefore, met all the criteria of RADS [5].

This case describes yet another environment that can lead to RADS and, therefore, another respiratory disease that can result from swine building exposure. This observation is important both as a medical and a medicolegal issue. RADS is a disease for which reparation is made by workers compensation boards of many countries. We do not know whether this represents an isolated case, or if some of the increased airway reponsiveness in swine building workers described in other reports represented some form of RADS [16, 17]. Knowing the toxic environment of swine confinement buildings, we believe it is likely that this case is not isolated. Special attention will have to be given in the future to look for this entity in swine building workers who present symptoms of airflow obstruction and increased airway responsiveness. The prevalence of reactive airways dysfunction syndrome in these workers remains to be determined. Swine confinement workers should be aware of this potential health consequence following exposure to high concentrations of toxic gases in their work environment.

\section{References}

1. Brooks SM, Weiss MA, Bernstein IL. Reactive airways dysfunction syndrome (RADS): persistent asthma syndrome after high level irritant exposures. Chest 1985; 88: 376-384.

2. Luo JC, Nelsen KG, Fishbein A. Persistent reactive airway dysfunction after exposure to toluene diisocynate. Br J Ind Med 1990; 47: 239-241.

3. Kern DG. Outbreak of the reactive airways dysfunction syndrome after a spill of glacial acetic acid. Am Rev Respir Dis 1991;144: 1058-1064.

4. Flury KE, Ames DE, Rodarte JR, Rodgers R. Airway obstruction due to inhalation of ammonia. Mayo Clin Proc 1983; 58: 389-393.

5. Alberts WM, Haley JA. Reactive airways dysfunction syndrome. Pulm Perspect 1992; 9: 1-4.

6. Gautrin D, Boulet LP, Boutet M, et al. Is reactive airways dysfunction syndrome a variant of occupational asthma? J Allergy Clin Immunol 1994; 93: 12-22.

7. Donham KJ, Popendorf WJ. Ambient levels of selected gases inside swine confinement buildings. Am Ind Hyg Assoc J 1985; 46: 658-661.

8. Bessette L, Boulet LP, Tremblay G, Cormier Y. Bronchial responsiveness to methacholine in swine confinement building workers. Arch Environ Health 1993; 48: 73-77.

9. Clark S, Rylander R, Larsson L. Airborne bacteria, endotoxin and fungi in dust in poultry and swine confinement buildings. Am Ind Hyg Assoc J 1983; 44: 537-541.

10. Donham KJ, Knapp LW, Monson R, Gustafson K. Acute toxic exposure to gases from liquid manure. $J$ Occup Med 1982; 24: 142-145.

11. Rylander R. Donham KJ, Hjort C, Brouwer R, Heederik D. Effects of exposure to dust in swine confinement buildings: a working group report. Scand J Work Environ Health 1989; 15: 309-312.

12. Juniper EF, Frith PA, Hargreave FE. Airway responsiveness to histamine and methacholine: relationship to minimum treatment to control symptoms of asthma. Thorax 1981; 36: 575-579.

13. Burnett WW, King EG, Grace M, Hall WF. Hydrogen sulphide poisoning: a review of five years experience. Can Med Assoc J 1977; 117: 1277-1280.

14. Kurt TL. Chemical asphyxiants. In: Rom William N.,Ed. Environmental and Occupational Medicine. Boston Mass., Little, Brown and Co., 1983; pp. 289-300.

15. Brooks SM, Bernstein IL. Reactive airways dysfunction syndrome or irritant-induced asthma. In: Bernstein IL, Cheng-Yeung M, Malo JL, Bernstein Al, eds. Asthma in the workplace. New York, Basel, Hong Kong, Marcel Dekker, 1993; pp. 533-549.

16. Zhou C, Hurst TS, Cockcroft DW, Dosman JA. Increase in airway hyperresponsiveness in swine farmers. Chest 1991; 99: 941-944.

17. Iversen M, Dahl R, Jensen EL, Korsgaard J, Hallas T. Lung function and bronchial reactivity in farmers. Thorax 1989; 44: 645-649. 